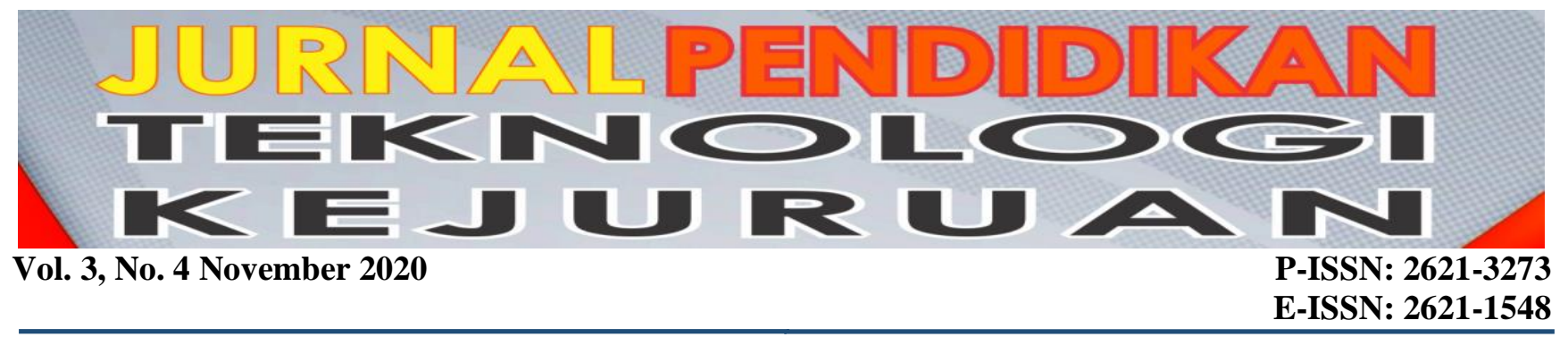

\title{
The Influence of Implementation Work-Based Learning Model on Learning Innovation Skills Student's
}

\author{
Irma Manda Negara ${ }^{1}$, Nurul Hidayati ${ }^{2}$ \\ 1,2,Sekolah Tinggi Bahasa Asing Pontianak, Indonesia \\ *Corresponding author, e-mail: irmamanda23@gmail.com
}

\begin{abstract}
This study aimed to analyze the influence of internship as a form of the WBL model to LIS students, in terms of the assessment theory of work-based learning and framework of 21st-century skills. The method used is descriptive quantitative, with respondents students who have done internships. The results showed that there are significant WBL (X) on critical thinking and problem-solving skills (Y1), indicated by the results of the significance value $0.000<0.050$ probability and the value of $t$, the obtained value of $t_{\text {count }} 6.177>t_{\text {table }} 2.024$. Next, there is the influence of WBL (X) on communication skills (Y2), seen from the significance value of $0.000<0.050$ probability. Then, for a value of $t$, obtained the value of $t_{\text {count }} 5,039>t_{\text {table }} 2,024$. There is the influence of WBL (X) on collaboration skills (Y3), seen at a significance value of $0.000<0.050$ probability. Then, for a value of $t$, the obtained value of $t_{\text {count }} 5,405>t_{\text {table }}$ 2,024. There is no significant and positive relationship between the implementation of WBL and students' Creativity and Innovation skills (Y4). This can be seen when the linearity test is carried out. The implementation of an internship can contribute to the development of skills covered in LIS, except for creativity and innovation skills.
\end{abstract}

Keywords: WBL, critical thinking and problem solving skills, communication skills, collaboration skills, creativity and innovation skills

\section{INTRODUCTION}

The implementation of education is required not only to be able to equip graduates with the knowledge, but also some other skills to prepare graduates to enter the workforce and be able to compete with all the changes. These skills that graduates need to succeed in carrying out life after graduation is a part of 21 st-century skills (Kivunja, 2014). Further, stated by Hilton (2015) policymakers and employers have urged have appealed to education implementing institutions to develop 21stcentury skills. These skills are better known as partnership 21st century skills.

According to (Triling \& Fadel, 2009) there are two main skills, which are included in the requirements of the workforce in the 21 st century, including: 1) the ability to acquire and apply new knowledge quickly; 2) the ability to understand how to apply 21 st-century skills. Therefore, it is important for education institusions to prepare students to assist students in developing essential skills in accordance with the qualification of the workforce of the 21 st century. Added, the need to integrate all the competencies and skills in the $21 \mathrm{st}$ century and the era of 4.0 into education (Ghufron, 2018).

Basically, there are many things that can be done by the education institutions, especially for educators to be able to help students develop their knowledge and skills to enter the workforce. Among them is to use the work-based learning strategy. Work-based learning (WBL) is a form of learning model with the principle of learning by doing. As well as emphasizing the form of formalizing the implementation of learning in the workplace (Van Velzen et al., 2012). Further, according Boud \& Solomon (2001) WBL is a learning program at the university by creating learning and new opportunities in the workplace. The characteristics of the WBL, are 1) the creation of partnerships between educational institutions and external institutions (DU / DI, the governmental institutions); 2) students involved were placed as a worker; 3 ) programs designed according to the needs of students, in this case the work carried out as a curriculum; 5) WBL is a project carried out in the workplace learning-oriented work challenges and needs of students in the future; 6) educational institutions assess the results of the WBL that adjust 
with the framework standards and levels as an element in the process of quality assurance of education. In short, it can be concluded that WBL is a program carried out by educational institutions that collaborate with external institutions, which is oriented towards the needs of students in the future.

Form of the WBL model is the internship (Siswanto, 2012). In the flow of implementation, internships are in accordance with the WBL concept, In the flow of implementation, internship accordance with the WBL concept is learning while working, providing work experience to students, and increasing knowledge and skills that are more trained than what they get at school. More importantly, provide provisions so that they can compete in the workforce. Triling \& Fadel (2009) state education have broad goals of preparing graduates who contribute to the workforce and daily life. Then, the era also requires workers who have the ability and knowledge of the skilled (Triling \& Fadel, 2009). Based on the presentation, it can be seen that the competencies and skills that are actually needed of the workforce in the 21 st century, and in this era, should be owned by the students as prospective employees.

There are three sets of skills required in the 21 st century, including "learning and innovation skills; information, media, and technology skills; life and career skills" (Triling \& Fadel, 2009, p.48). This study aims to analyze the influence of the implementation of internships (as a model of WBL) on students' learning innovation skills (LIS). The theory used to measure these two main variables, namely the theory of Raelin (2008) and (Triling \& Fadel (2009). The selection of LIS variables is based on these skills, which are creative learning skills and lifelong learning, then these skills can handle the demands of skills in the new era and focus on creation, as well as creativity. Furthermore, this study is a follow-up research conducted by the first researcher with the title "Kontribusi Pengalaman Praktik Kerja Industri Terhadap Life Skill, Career Skills, dan Tehnology Skills Siswa SMK Bidang Keahlian Teknologi Industri Kota Pontianak" where this research also use the framework partnership 21st century skills, but with elements of the other skills (Manda Negara, 2014).

\section{METHOD}

This study uses a descriptive quantitative approach, to obtain objective and precise measurement results (Leavy, 2017). The sampling technique used was purposive sampling, by taking all the total respondents. These respondents deliberately have chosen because it can provide information based on knowledge and experience (Etikan, 2016). There are 40 students who have done internships. The data collection technique used a questionnaire consisting of two variable components, are WBL (X) and critical thinking and problem-solving skills (Y1), communication skills (Y2), collaboration skills (Y3), and creativity and innovation skills (Y4). Where each of these variables, consisting of several indicators to building a questionnaire. For variable WBL, referring to the theory Raelin (2008), and for variable LIS, referring to the theory Triling \& Fadel, (2009), described as the table below:

Table 1. Indicator Variable

\begin{tabular}{|c|c|c|}
\hline No & Variable & Indicators \\
\hline 1 & WBL & $\begin{array}{l}\text { 1. Academic } \\
\text { development } \\
\text { 2. Personal development } \\
\text { 3. Career development }\end{array}$ \\
\hline 2 & LIS & $\begin{array}{l}\text { 1. Critical thinking and } \\
\text { problem-solving } \\
\text { 2. Communication skills } \\
\text { 3. Collaboration skills } \\
\text { 4. Creativity and } \\
\text { innovation skills }\end{array}$ \\
\hline
\end{tabular}

(Raelin, 200; Triling \& Fadel, 2009)

The preparation of the questionnaire has been through a validation process, to seek advice from experts and conducting field trials which are then calculated for validity and reliability.

\section{RESULT}

Results of analysis is a statistical analysis, using simple regression analysis. The analysis test is carried out to determine the requirements, including the normality test for each variable and the linearity test.

Tabel 2. Normality Test

\begin{tabular}{cccc}
\hline Variables & $\begin{array}{c}\text { Asymp. } \\
\text { Sig }\end{array}$ & Significance & Judgment \\
\hline $\mathrm{X}$ & 0.876 & 0.05 & Normal \\
\hline Y1 & 0.665 & 0.05 & Normal \\
\hline Y2 & 0.402 & 0.05 & Normal \\
\hline Y3 & 0.304 & 0.05 & Normal \\
\hline Y4 & 0.672 & 0.05 & Normal \\
\hline
\end{tabular}

Decision-making is based on a reference value of Asymp. Significance greater than 0.05 , then the data distribution is normal. Thus, the decision 
normality test based on the data above, it can be concluded that the data is normally distributed.

The criteria for the linearity test is based on the assumptions below:

a. Ho is accepted (variables $\mathrm{X}$ and $\mathrm{Y}$ have a linear relationship): If the value of $\mathrm{F}_{\text {count }}<\mathrm{F}_{\text {tab }}$, and the value of sig $>0.05$.

b. Ho is rejected (variables $\mathrm{X}$ and $\mathrm{Y}$ do not have a linear relationship): If the value of $F_{\text {count }}>F_{\text {tab }}$, and the value of sig $<0.05$.

Based on this provision, showed the following results:

Table 3. Summary of Linearity Test

\begin{tabular}{cccccc}
\hline Variables & Fcount & $\begin{array}{c}F \\
\text { table }\end{array}$ & Sig. & $\begin{array}{c}\text { Sig. } \\
\text { level }\end{array}$ & judgment \\
\hline $\mathrm{X}^{*} \mathrm{Y}$ & 1.857 & 2.14 & .109 & .050 & Linier \\
\hline $\mathrm{X}^{*} \mathrm{Y} 2$ & 1.277 & 2.14 & .317 & .050 & Linier \\
\hline $\mathrm{X}^{*} \mathrm{Y} 3$ & 1.124 & 2.14 & .416 & .050 & Linier \\
\hline $\mathrm{X}^{*} \mathrm{Y} 4$ & 2.597 & 2.14 & .030 & .050 & Not linier \\
\hline
\end{tabular}

Referring to the description of the results above, only the variable $\mathrm{X} * \mathrm{Y} 1 ; \mathrm{X} * \mathrm{Y} 2$; and $\mathrm{X} * \mathrm{Y} 3$ followed by regression analysis to test the hypothesis.Influence of WBL (X) to Critical Thinking and problem-solving skills (hypothesis 1)

Table 4. Summary of simple regression analysis WBL (X) on critical thinking and problem-solving skills (Y1)

\begin{tabular}{cccccc}
\hline Variable & $\begin{array}{c}\text { Constant } \\
(\boldsymbol{B})\end{array}$ & $\begin{array}{c}\text { T } \\
\text { count }\end{array}$ & T tab & sig & $\begin{array}{c}\text { Sig. } \\
\text { Level }\end{array}$ \\
\hline \multirow{2}{*}{$\mathrm{X}^{*} \mathrm{Y} 1$} & -1.613 & & & & \\
\cline { 2 - 6 } & .340 & 6.177 & 2.024 & .000 & 0.05 \\
\hline
\end{tabular}

Based on Table 4, concluded the regression equation $\mathrm{Y}=-1613+0.340 \mathrm{X}$. The significance value is 0.000 $<0.050$ probability. Then, for a value of $t$, obtained $t_{\text {count }}$ value $6,177>2,024 t_{\text {table. }}$. Based on these findings, it was concluded that "there is an influence of WBL $(\mathrm{X})$ on critical thinking and problemsolving skills (Y1).

1. Influence of WBL (X) to communication skill (Y2) (hypothesis 2)

Table 5. Summary of simple regression analysis WBL (X) on communication skill (Y2)

\begin{tabular}{cccccc}
\hline Variable & $\begin{array}{c}\text { Constant } \\
(B)\end{array}$ & $\begin{array}{c}\text { T } \\
\text { count }\end{array}$ & T tab & sig & $\begin{array}{c}\text { Sig. } \\
\text { Level }\end{array}$ \\
\hline
\end{tabular}

\begin{tabular}{cccccc}
\hline Variable & $\begin{array}{c}\text { Constant } \\
(\boldsymbol{B})\end{array}$ & $\begin{array}{c}\text { T } \\
\text { count }\end{array}$ & T tab & sig & $\begin{array}{c}\text { Sig. } \\
\text { Level }\end{array}$ \\
\hline \multirow{2}{*}{$\mathrm{X}^{*} \mathrm{Y} 2$} & 8.339 & 5.039 & 2.024 & .000 & 0.05 \\
\cline { 2 - 6 } & .165 & & & & \\
\hline
\end{tabular}

Based on Table 5, concluded the regression equation $\mathrm{Y}=8.339+0.165 \mathrm{X}$. The significance value is 0.000 $<0.050$ probability. Then, for a value of $t$, obtained $\mathrm{t}_{\text {count }}$ value $5,039>2,024 \mathrm{t}_{\text {table. }}$. Based on these findings, it was concluded that "there is an influence of WBL (X) on communication skill (Y2).

2. Influence of WBL (X) to collaboration skill (Y3) (hypothesis 3)

Table 6. Summary of simple regression analysis WBL (X) on collaboration skill (Y3)

\begin{tabular}{cccccc}
\hline Variable & $\begin{array}{c}\text { Constant } \\
(\boldsymbol{B})\end{array}$ & $\begin{array}{c}\boldsymbol{T} \\
\text { count }\end{array}$ & T tab & sig & $\begin{array}{c}\text { Sig. } \\
\text { Level }\end{array}$ \\
\hline \multirow{2}{*}{$\mathrm{X}^{*} \mathrm{Y} 3$} & 3.245 & 5.405 & 2.024 & .000 & 0.05 \\
\cline { 2 - 6 } & .169 & & & & \\
\hline
\end{tabular}

Based on Table 6, concluded the regression equation $\mathrm{Y}=3.245+0.169 \mathrm{X}$. The significance value is 0.000 $<0.050$ probability. Then, for a value of $t$, obtained $\mathrm{t}_{\text {count }}$ value $5,405>2,024 \mathrm{t}_{\text {table. }}$. Based on these findings, it was concluded that "there is an influence of WBL (X) on collaboration skill (Y3).

\section{DISCUSSION}

This study aims to identify and analyze the influence of the implementation of WBL on Learning Innovation Skills (LIS). The main reason that the implementation of WBL is carried out by the institution is to equip students with work experience and, in order to students get an overview of the world of work, including the qualifications needed by the working world. Because along with the times, the demands on the qualifications also increasingly complex. Where it not only requires skills in terms of knowledge, but also several components of other skills, and including the LIS. As stated by Sudira (2015) in his research, that 21st century work tends to be complex and complicated, requiring collaborative work with people with different cultures and work disciplines, communicating through various media, and implementing problem solving.

Based on the results of the analysis, there is a significant and positive influence of the implementation of WBL on the skills component of LIS, namely critical thinking and problem-solving skills; communiction skills; and collaboration skills. 
Meanwhile, creativity and innovation skills do not have a significant influence. This is similar to research conducted by Mustika et al (2017) It was found that there was an influence between apprenticeship on student soft skills. Soft skills in this study represent written communication skills, critical thinking skills and interpersonal understanding. Furthermore, problem solving skills are the most representative skills of soft skills.

An article published results of the data collection showed that there is a positive correlation between 21 st century skills development and future work quality, and problem-solving skills are the most significant stimulant for higher quality work (Microsoft Partners in Learning \& Gallup, 2013). Furthermore, the skills of the 21st century need to be developed and maximized to each student in order to achieve success in life because they have a high quality of work, and this development is given consistently particularly at the end of the students complete their education (Microsoft Partners in Learning \& Gallup, 2013). Based on this statement, it is considered very appropriate to implement WBL at the higher education level, especially in the final semester as a means to help students develop 21st century skills, and one of them is LIS.

\section{CONCLUSION}

Based on the results of the research analysis, it can be concluded that: (1) there is a positive and significant influence between the implementation of WBL (X) and on Critical Thinking and problem solving skills (Y1). This can be seen in the R Square value of 0.501 . This value means that there is an influence of implementation of WBL (X) on critical thinking and problem-solving skills (Y1) of $50.1 \%$, while $49.9 \%$ of critical thinking and problem-solving skills are influenced by substances other variables not studied; (2) there is a positive and significant influence between the implementation of WBL (X) and on communication skills (Y2). This can be seen in the R Square value of 0.401 . This value means that there is an influence of implementation of WBL (X) on communication skills (Y2) of $40.1 \%$, while $59.9 \%$ of communication skills are influenced by substances other variables not studied; (3) there is a positive and significant influence between the implementation of WBL (X) and on collaboration skills (Y3). This can be seen in the R Square value of 0.435 . This value means that there is an influence of implementation of WBL (X) on collaboration skills (Y3) of $43.5 \%$, while $56.5 \%$ of collaboration skills are influenced by substances other variables not studied; (4) there is no significant and positive influence between the implementation of WBL and
Creativity and Innovation skills (Y4). This is evident at the time of the linearity test.

\section{REFERENCES}

Boud, D., \& Solomon, N. (2001). Work-Based Learning A New Higer Education? SRHE and Open University Press.

Etikan, I. (2016). Comparison of Convenience Sampling and Purposive Sampling. American Journal of Theoretical and Applied Statistics, 5(1), 1. https://doi.org/10.11648/j.ajtas.20160501.11

Ghufron, G. (2018). Revolusi Industri 4.0: Tantangan, Peluang, Dan Solusi Bagi Dunia Pendidikan. Seminar Nasional Dan Diskusi Panel Multidisiplin Hasil Penelitian Dan Pengabdian Kepada Masyarakat 2018, 1(1), 332-337. proceeding.unindra.ac.id

Hilton, M. (2015). Preparing students for life and work. Issues in Science and Technology, 31(4), 63-66. https://doi.org/10.1163/9789004393073

Kivunja, C. (2014). Innovative Pedagogies in Higher Education to Become Effective Teachers of 21st Century Skills: Unpacking the Learning and Innovations Skills Domain of the New Learning Paradigm. International Journal of Higher Education, 3(4), 37-48. https://doi.org/10.5430/ijhe.v3n4p37

Leavy, P. (2017). Research Design Quantitative, Qualitative, Mixed Methods, Arts-Based, and Community-Based Participatory Research Approaches. The Guilford Press.

Manda Negara, I. (2014). Kontribusi Pengalaman Praktik Kerja Industri Terhadap Life Skills, Career Skills, dan Technology Skills Siswa SMK Bidang Keahlian Teknologi Industri Kota Pontianak (Issue 3) [Yogyakarta State University]. https://eprints.uny.ac.id/12547/

Microsoft Partners in Learning, P. F., \& Gallup. (2013). 21st Century Skills and the Workplace: A 2013 Microsoft Partners in Learning and Pearson Foundation Study. 21 St Century Skills and the Workplace. https://news.gallup.com/

Mustika, R. C., Nurjanah, N., \& Chisbiyah, L. A. (2017). Pengaruh Praktik Kerja Lapangan Terhadap Soft Skill Siswa Smk Bidang Keahlian Jasa Boga Di Kota Malang. Teknologi Dan Kejuruan: Jurnal Teknologi, Kejuruan, Dan Pengajarannya, 40(2), 147-156.

https://doi.org/10.17977/um031v40i22017p147

Sudira, P. (2015). Pengembangan Model "LIS-5C" Pada Pendidikan TEeknologi Dan Kejuran. Cakrawala Pendidikan: Jurnal Ilmiah Pendidikan, 1, 1-11. https://doi.org/10.21831/cp.v1i1.4145

Raelin, J. . (2008). Work-Based Learning Bridging Knowledge and Action in the Workplace. Jossey Bass. https://doi.org/10.1002/9781118472361.ch7

Siswanto, B. T. (2012). Model Penyelenggaraan WorkBased Learning Pada Pendidikan Vokasi Diploma III Otomotif. 2(2), 11-26. 
https://doi.org/https://doi.org/10.21831/jpv.v2i1.101 3

Triling, B., \& Fadel, C. (2009). 21st Century Skills Learning for Life in Our Times. In 21St Century Skill (Issue Book). Jossey Bass.

Van Velzen, C., Volman, M., Brekelmans, M., \& White, S. (2012). Guided work-based learning: Sharing practical teaching knowledge with student teachers. Teaching and Teacher Education, 28(2), 229-239. https://doi.org/10.1016/j.tate.2011.09.011 